\title{
VIRAL RUSH CAUSED BY PARECHOVIRUS MISTAKEN AND TREATED AS ALLERGY
}

\section{Background and Aims}

Parechoviruses are associated with a wide disease spectrum similar to the echoviruses. These include febrile syndromes, respiratory tract infections, exanthema, viral meningitis, encephalitis, myocarditis and severe neonatal infections.

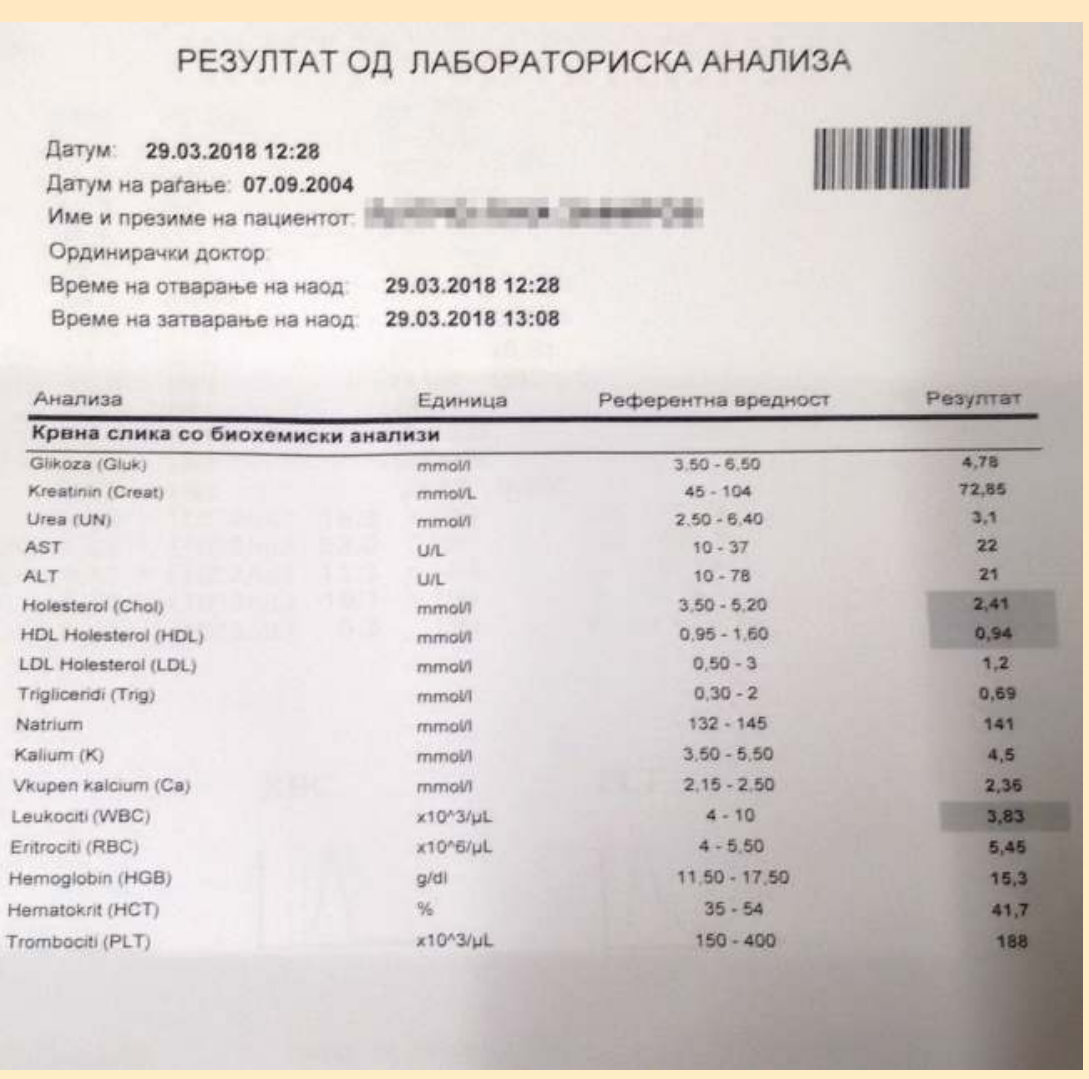

Leucopenia (3.83*109 cells/L)

Nevertheless, the majority of pediatric viral infections are mild in nature and manifest as the common cold and pharyngitis. However, if not resolved, patients can become febrile, accompanied by vomiting, diarrhoea with a severe rash.

\section{Method}

A 15-year-old boy was referred to our clinic due to exanthema and a "migrating" macular rash. An infectiologist previously diagnosed his symptoms as an allergy and prescribed anti-histamines.

Nevertheless, the symptoms worsened as the boy became febrile, his clinical presentation and leucopenia $\left(3.83 * 10^{9}\right.$ cells/L) suggested a possible viral aetiology, despite the infectiologist's report. We performed a multiplex PCR analysis for a panel of viral pathogens that included Influenza, Parainfluenza, Corona, Human Metapneu-, Picorna-, Respiratory Synctial, Adeno-, Boca- and Parechoviruses.

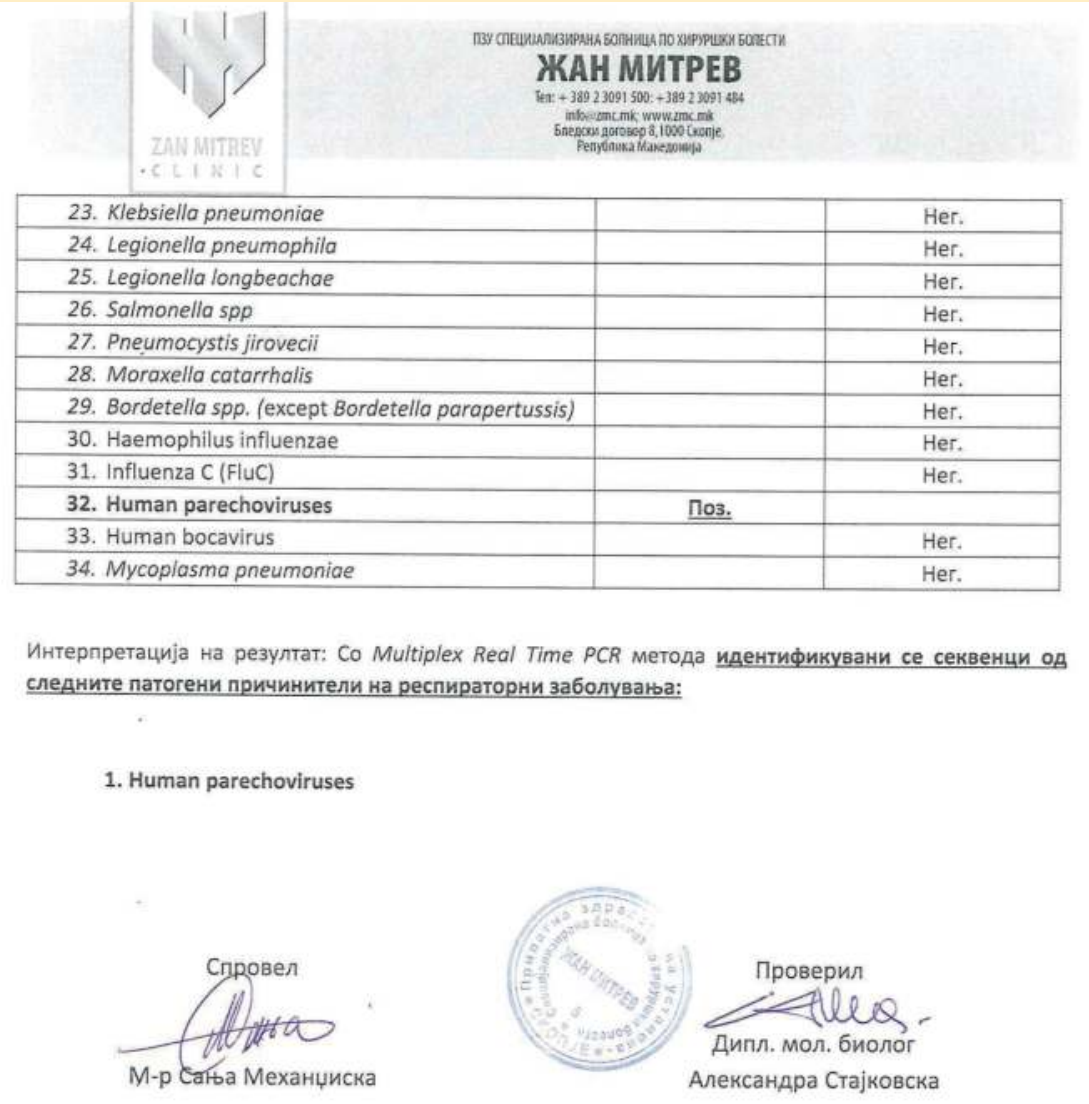

PCR analysis for a panel of viral and becterial pathogens

\section{Results}

The test pointed to a Parechovirus infection; antihistamine treatment was ceased, and we initiated supportive care. Besides leucopenia, biochemical analyses failed to reveal other abnormalities. Our treatment approach was successful; patient was afebrile after 48 hours and his white blood counts normalized.

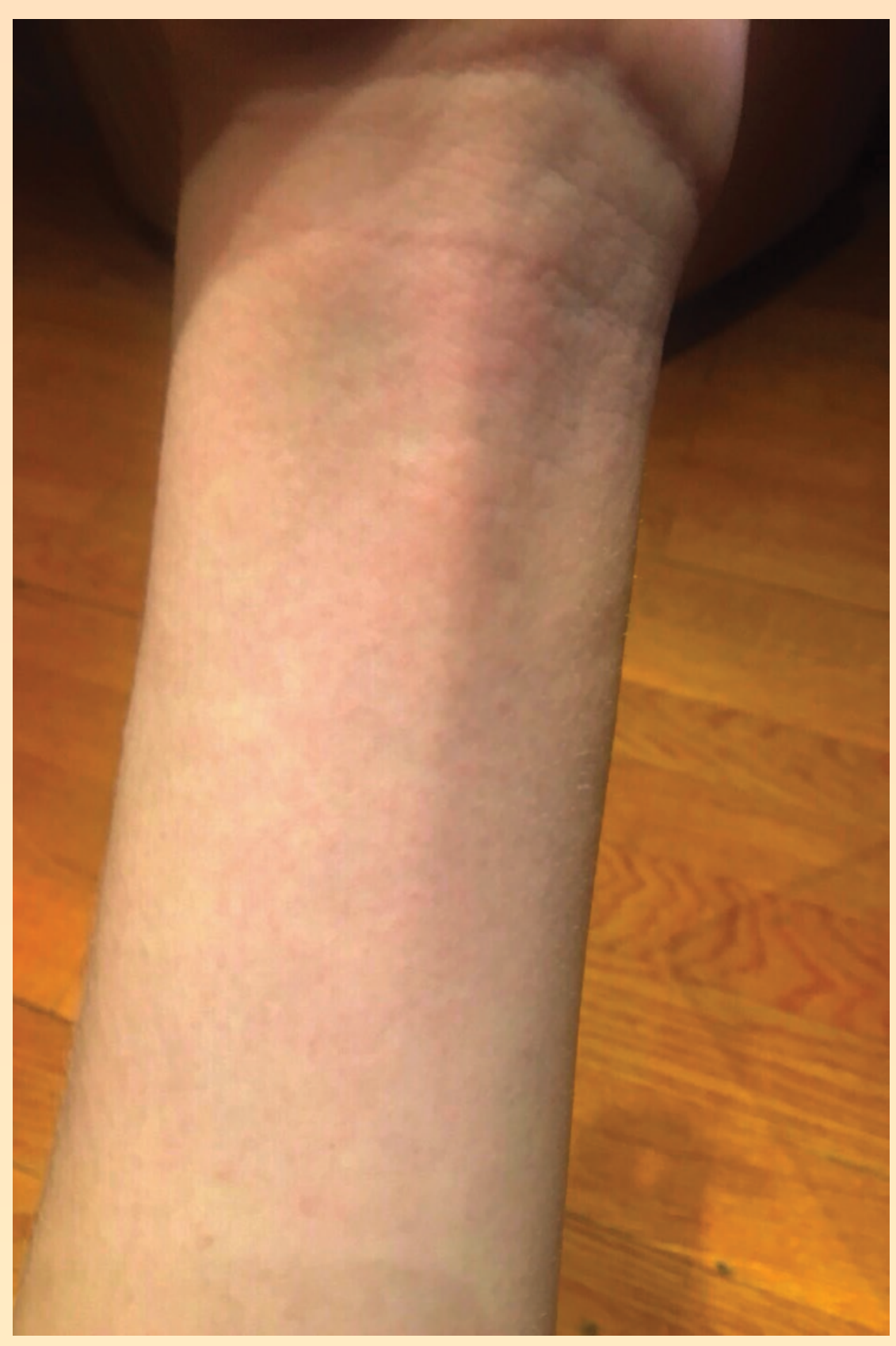

Skin rush

\section{Conclusion}

Clinicians should consider, exclude, viral etiology upon the presentation of severe skin rashes, clinical diligence is especially warranted when basic anti-allergic medication fails to improve a patient's clinical condition.

\section{References}

Levin S, Goodman LJ. An approach to acute fever and rash (AFR) in the adult. In: Current Clinical Topics in Infectious Diseases, Remington JS, Swartz MN (Eds), Blackwell Science, Boston 1995. p.19.

Weber DJ, Cohen MS, Rutala WA. The acutely ill patient with fever and rash. In: Principles and Practices of Infectious Diseases, 8th ed, Bennett JE, Dolin R, Blaser MJ (Eds), Elsevier Saunders, Philadelphia 2015. p.732.

Valdez, LM, Septimus, EJ. Clinical approach to rash and fever. Infect Dis Pract 1996; 20:1.

Sumaya CV. Acute exanthematous disease. In: Infectious Diseases of Children and Adults. A Stepby-Step Approach to Diagnosis and Treatment, Pickering LK, DuPont HL (Eds), Addison-Wesley, Menlo Park, CA 1986. p.167.

Sanders CV. Approach to the diagnosis of the patient with fever and rash. In: The Skin and Infection: A Color Atlas and Text, Sanders CV, Nesbitt LT Jr (Eds), Williams and Wilkins, Baltimore 1995. p.296. 